\title{
POINTS OF VIEW
}

\section{EDITORIAL}

\section{Reflections on Katrina}

\author{
John H. Perkins
}

Hurricane Katrina passed over the Louisiana and Mississippi Gulf Coast approximately 10 to 15 miles from New Orleans on August 29, 2005, and the challenges facing everyone, including environmental professionals, escalated to levels seldom encountered. New Orleans ceased to exist as a functioning city and the coastline for miles lay devastated.

Environmental professionals were among the first responders to this disaster. Their work began immediately and focused on factors that threatened human health. ${ }^{1}$ Among the most important were:

- removing the floodwaters;

- assessing and restoring drinking water;

- restoring wastewater treatment facilities;

- disposing of debris;

- assessing and cleaning sediments, possibly contaminated with chemicals;

- restoring electrical power and natural gas;

- providing occupational health guidelines for the cleanup;

- controlling disease vectors and rodents;

- assessing damage to underground and above-ground storage tanks;

- managing buildings and debris contaminated by molds; and

- establishing guidelines on food safety.

To get a sense of the magnitude of the problems, consider a few details. Twenty-two million tons of debris required disposal in Louisiana. Food and curbside trash, con- struction and demolition debris, and hazardous materials each had to go to a separate kind of landfill. Downed trees had to be removed. The United States Environmental Protection Agency (USEPA) collected over one million pounds of household hazardous wastes for disposal. ${ }^{2}$

Problems with mold in New Orleans alone were sufficient to create a major problem. An estimated $60 \%$ to $80 \%$ of the structures in the city were damaged from immersion 48 hours or more in floodwaters, some up to 25 feet in depth. These conditions supported the growth of potentially hazardous molds. Residents returning to their homes and workers doing repairs were subject to exposures, primarily by inhalation. About 200 species of fungi are thought to cause health hazards, including allergic reactions, exacerbation of asthma, and hypersensitivity pneumonitis. Ingestion can sometimes be a problem, as in consuming spoiled food contaminated with aflatoxin, a mold by-product that can cause liver cancer or liver failure. ${ }^{3}$

Contamination from chemicals and oil affected some areas. Murphy Oil USA has a refinery with associated pipelines and docks on the Mississippi River in St. Bernard Parish. Katrina dislodged a storage tank containing 65,000 barrels of crude oil. Over 25 ,000 barrels worth was released (1.05 million gallons), contaminating 1,700 houses, several canals, and over a square mile of land. As of early November, many soil samples in the contaminated area were still showing levels of heavy metals (arsenic, cadmium, and chromium) and a multitude of volatile organic compounds above regulatory levels of the USEPA and Louisiana Department of Environmental Quality.

Katrina's massive damages caused horrendous problems to governments dealing with the issues. Poor responses from the federal government led to intense criticism of officials at the very highest level and ulti- mately forced the resignation of Michael D. Brown, head of FEMA (Federal Emergency Management Agency). Other criticisms fell on state and local leaders.

Only the federal government, however, had the resources needed to respond to the disaster. The damage made refugees of most of the residents of New Orleans and undermined the city's infrastructure. Countless other smaller cities and towns in Louisiana, Mississippi, and Alabama are also out of commission. Hurricane Rita's subsequent onslaught against Texas and Louisiana simply added to the catastrophe. The appropriate comparison for Katrina and Rita is the 1986 explosion of the Chornobyl nuclear power plant in Ukraine. There, too, a large area was depopulated and a major source of electrical power was eliminated (vast areas of land in Ukraine and Belarus are still difficult or impossible to inhabit due to radionuclide contamination).

Ethical, political, and practical problems pervade the reconstruction. Will shortcuts be taken, again, with the protection of the city? Local newspapers in New Orleans charge that in the last few years the US Army Corps of Engineers was stripped of money for levee work in order to support the war in Iraq. ${ }^{5}$ From a different point of view, critics have argued that the protection of New Orleans from hurricanes should rely more on wetland restoration than on man-made devices. Even more fundamental among the ethical issues in protecting the city is whether it should be rebuilt on its current site.

New Orleans will probably be restored to its former vitality. As others have pointed out, the Port of New Orleans is too vital to the commerce of the entire MississippiMissouri-Ohio river valleys not to be restored. ${ }^{6}$ New Orleans' reconstruction will be a necessary support for the Port. In addition, and on a somewhat lighter note, can we ever imagine a United States without Mardi Gras? 
For its part, I am proud that the Board of the National Association of Environmental Professionals (NAEP), after a vigorous and meaningful debate, agreed to try and help. The NAEP created a list of environmental professionals willing to lend a hand in the reconstruction of areas receiving Katrina damage. This was a small but important ethical step, and the issues facing the Board in taking it were not trivial. The NAEP's actions won't fix everything, but it is a step in the right direction.

\section{Notes}

1. Joint Task Force of the Centers for Disease Control and Prevention and the US Environ- mental Protection Agency, 2005, "Environmental Health Needs and Habitability Assessment," September 17, www.bt.cdc.gov/disasters/ hurricanes/Katrina/envassessment.asp; Centers for Disease Control and Prevention Mold Work Group, 2005, "Mold: Prevention Strategies and Possible Health Effects in the Aftermath of Hurricanes Katrina and Rita," October, www.bt.cdc/gov/disasters/mold/report.

2. Louisiana Department of Environmental Quality, 2005, "DEQ Focuses on Disposal of 22 Million Tons of Debris from Katrina and Rita," November 7, www.deq.state.la.us/news/pdf/ Debrisdisposalpressrelease117.pdf.

3. Centers for Disease Control and Prevention Mold Work Group, 2005, "Mold"; Joint Task Force of the Centers for Disease Control and Prevention and the US Environmental Pro- tection Agency, 2005, "Environmental Health Needs and Habitability Assessment."

4. Centers for Disease Control and Prevention, 2005, "Murphy Oil Spill," www.bt.cdc.gov/ disasters/Katrina/murphyoil.

5. W. Bunch, 2005, "Did New Orleans Catastrophe Have to Happen? Times-Picayune Had Repeatedly Raised Federal Spending Issues," New Orleans Times-Picayune, August 30.

6. G. Friedman, 2005, "New Orleans: A Geopolitical Prize," Geopolitical Intelligence Report, September 3, www.stratfor.com/news/archive/ 050903-geopolitics_katrina.php.

Address correspondence to John H. Perkins, The Evergreen State College, Olympia, WA 98505; (fax) 360-867-5430; (e-mail)perkinsj@evergreen.edu. 